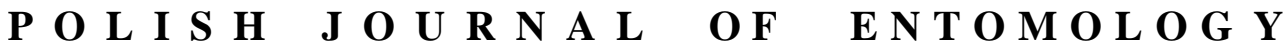

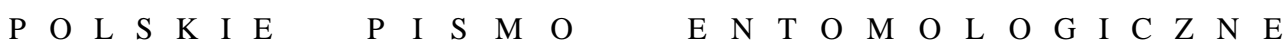

VOL. 83: 109-119

Lublin

30 June 2014

DOI: $10.2478 /$ pjen-2014-0008

\section{Distribution of Sceliphron curvatum SMITH, 1870 (Hymenoptera, Sphecidae) in Poland}

\author{
PIOTR BILAŃSKI ${ }^{1}$, ZBIGNIEW KOŁODZIEJ ${ }^{2}$, JAROSŁAW BURY ${ }^{3}$ \\ ${ }^{1}$ Department of Forest Protection, Forest Entomology and Climatology, Faculty of Forestry, \\ University of Agriculture in Kraków, al. 29. Listopada 46, 31-425 Kraków, Poland, \\ e-mail: rlbilans@cyf-kr.edu.pl \\ ${ }^{2}$ Department of Silviculture, Faculty of Forestry, University of Agriculture in Kraków, \\ al. 29. Listopada 46, 31-425 Kraków, Poland, e-mail: rlkolodz@cyf-kr.edu.pl \\ ${ }^{3}$ Markowa 1498, 37-120 Markowa, Poland, e-mail: jarekbury2@wp.pl
}

\begin{abstract}
In Poland, 31 new localities of Sceliphron curvatum (SMITH, 1870) have been found, including 23 documented localities and 8 undocumented localities requiring confirmation. Based on the locations of the new localities of $S$. curvatum as well as those already known from the literature, it has been possible to map where in Poland this species appears as well as the northern limits of its range.
\end{abstract}

KEY WORDS: expansion, migration, digger wasp, Sphecidae, new records.

\section{INTRODUCTION}

European mud-daubing wasps (genus Sceliphron KLUG, 1801) including introduced species comprise 7 representatives: Sceliphron caementarium (DRURY, 1770), S. curvatum (SMITH, 1870), S. destillatorium (ILliger, 1807), S. funestum (KOHL, 1918), S. madraspatanum ssp. tubifex (LATREILle, 1809), S. spirifex (LinNAeUs, 1758) (VECHT \& BREUGEL 1968, HENSEN 1987) and the recently discovered S. deforme (SMITH, 1856) (ĆETKOVIĆ et al. 2004). Two of them, S. destillatorium and S. curvatum, are present in Poland (Fig. 1). Information about the distribution of $S$. destillatorium in Poland has been presented in previous articles (BURY et al. 2009, BILAŃSKI et al. 2012) and has been summarised by 
MADER (2013).

S. curvatum appeared in Europe in the 1970s (VECHT 1984), most likely having been carried over from its natural habitat in Central Asia. Since its appearance, the species has been expanding continuously in Europe (ĆETKOVIĆ et al. 2004, BogusCH et al. 2005, SCHMID-EGGER 2005, BITSCH \& BARBIER 2006, CASTRO 2007, BOGUSCH et al. 2007, BURY et al. 2009, Bitsch 2010, PROKOFIEV \& SKOMOROKHOV 2010, RASPlus et al. 2010, SHORENKO \& KONOVALOV 2010, ĆETKOVIĆ et al. 2011).

Investigations into the distribution of S. destillatorium in Poland (BURY et al. 2009, BILAŃSKI et al. 2012) have also confirmed the presence of S. curvatum.

The aim of this work is to present the current state of knowledge concerning the distribution of $S$. curvatum localities in Poland. Localities already known from the literature are placed on the distribution map side-by-side with those discovered during the investigations.

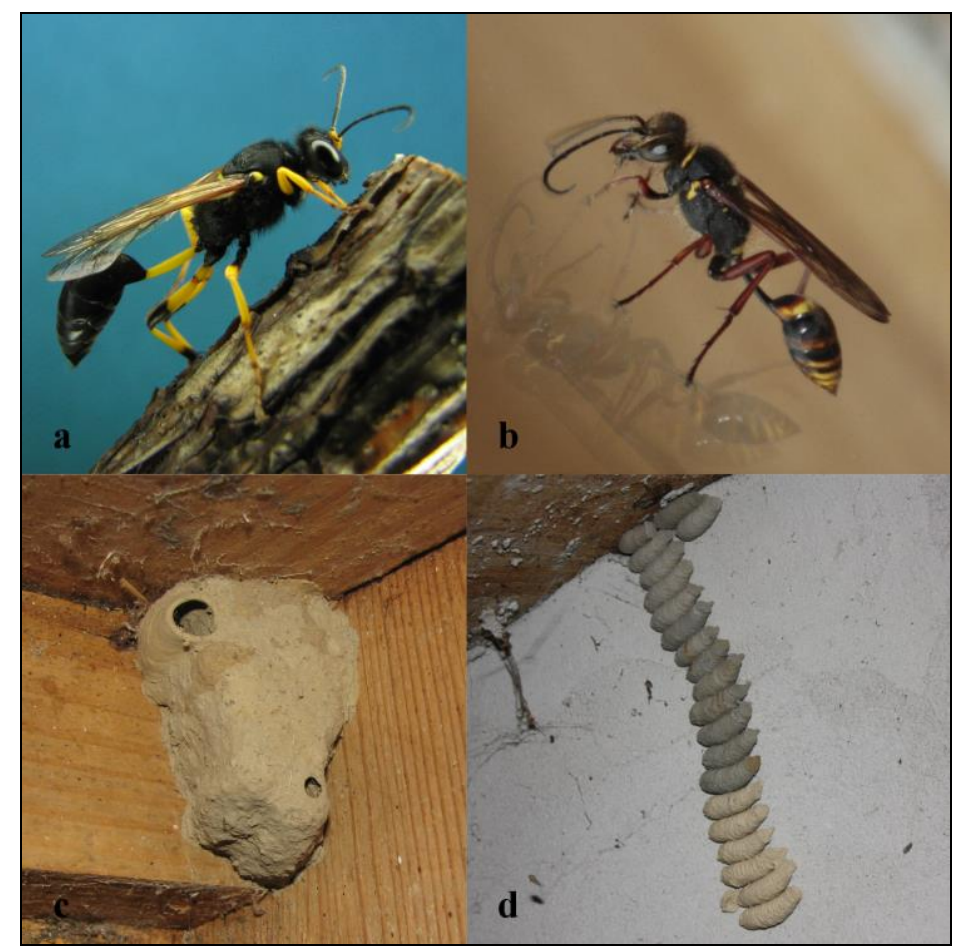

Fig. 1. Habitus of imago and nest of Sceliphron destillatorium (a, c) and S. curvatum (b, d) (photos by P. BILAŃSKI). 


\section{Acknowledgements}

The study was carried out within the framework of statutory activities, No. 3416/KOLEiKL financed by the Ministry of Science and Higher Education Republic of Poland.

\section{MATERIALS AND METHODS}

Faunistic information and other evidence regarding the occurrence of S. curvatum was gathered from 2007 to 2013. During this time, nests were collected, imagines were bred or collected in the field, and new localities were photographed. The collected insects and nests, as well as all the photographic documentation, have been deposited at the Department of Forest Protection, Forest Entomology and Climatology, University of Kraków. The wasps were identified and named according to SCHMID-EGGER (2005). The locations of new as well as previously known localities were marked on a map of Poland with a superimposed UTM grid. The new localities have been grouped in the text according to faunistical areas following the Catalogue of Fauna of Poland (BURAKOWSKI et al. 2000). Undocumented localities were also taken into account if their presence in a given area was highly probable based on documented localities. Information concerning localities needing confirmation came mostly from amateur naturalists.

The probable extent of the occurrence of $S$. curvatum in Poland was plotted on the basis of the distribution of extreme localities.

\section{RESULTS}

During investigations into the distribution of S. curvatum in Poland, the presence of this species was confirmed in 31 as yet undescribed localities, located in 25 UTM grid squares (Fig. 2). Among the new localities, 23 are documented with material evidence in the form of imagines and nests or photographs of them. The remaining 8 localities still require material evidence for their confirmation.

Some $48 \%$ of the new localities were described on the basis of imagines and $29 \%$ were described based on nests. $20 \%$ of the localities were those where both imagines and nests were found. Females were sighted almost four times as often as males.

The highest number of localities (6) was in Kraków. In one of these localities, S. curvatum was confirmed 3 times. 


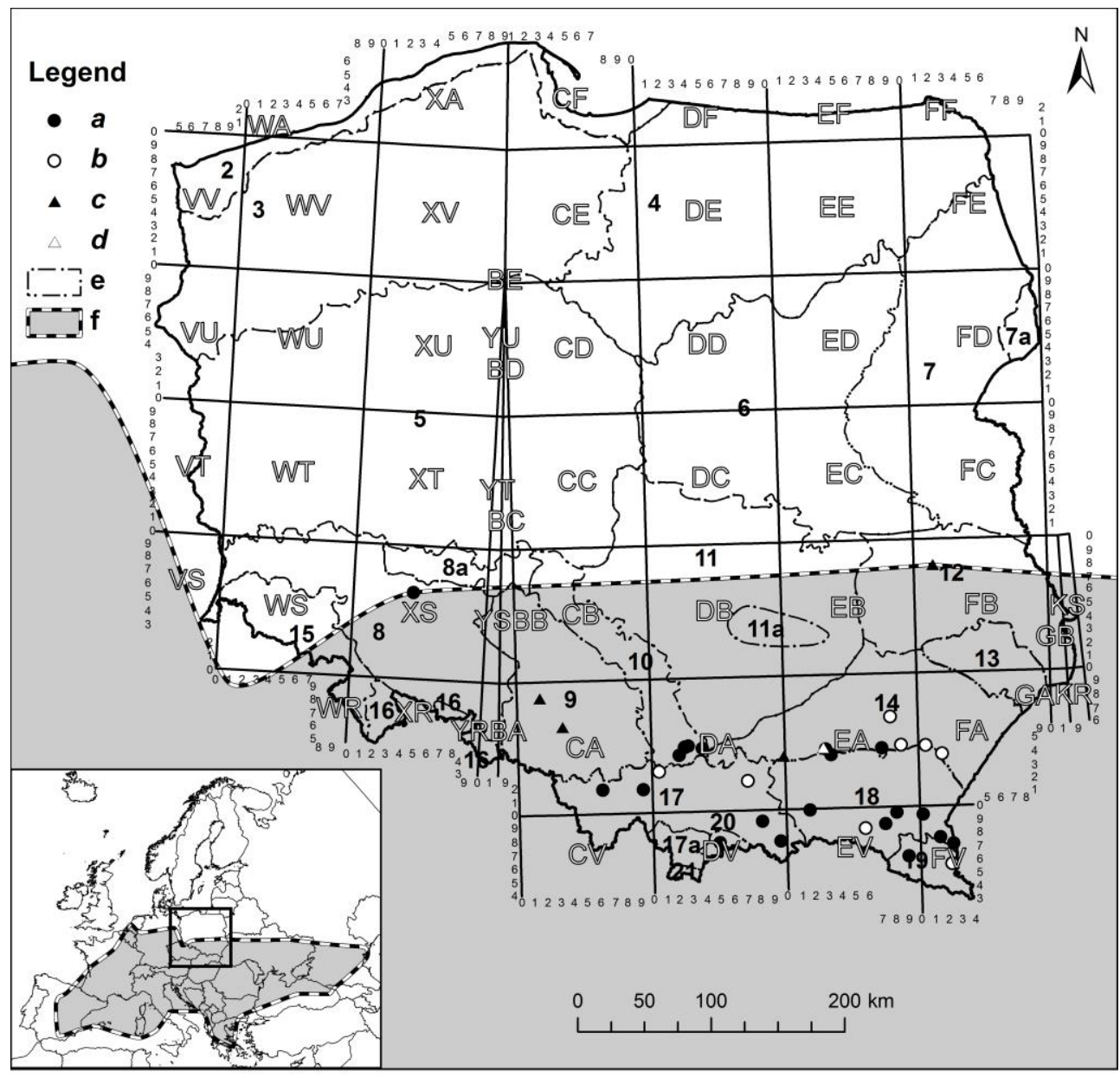

Fig. 2. Distribution map of Sceliphron curvatum SMITH, 1870 in Poland and the northern limits of its range (UTM grid map). Explanations: a - documented new localities of $S$. curvatum, b - undocumented new localities, c - documented localities known from the literature, $\mathrm{d}$ - undocumented documented localities known from the literature, $\mathrm{e}$ - faunistical regions according to the Catalogue of Fauna of Poland (BURAKOwSKI et al. 2000) (2 - Baltic Coast, 3 - Pomeranian Lake District, 4 - Masurian Lake District, 5 - Wielkopolska-Kujawy Lowland, 6 - Mazovian Lowland, 7 - Podlasie Lowland, 7a - Białowieża Primeval Forest, 8 - Lower Silesia, 8a - Trzebnica Hills, 9 - Upper Silesia, 10 - Kraków-Wieluń Upland, 11 - Małopolska Upland, 11a - Świętokrzyskie Mountains, 12 - Lublin Upland, 13 - Roztocze, 14 - Sandomierz Lowland, 15 - Western Sudetes Mountains, 16 - Eastern Sudetes Mountains, 17 - Western Beskid Mountains, 17a - Nowy Targ Basin, 18 - Eastern Beskid Mountains, 19 - Bieszczady Mountains, 20 - Pieniny Mountains, 21 - Tatra Mountains), f - geographic range of species and limits of its range. 
25 of the 31 described localities were situated inside buildings. There were only two observations of imagines in meadows.

The localities of S. curvatum at Rozpucie and Stasiówka dating from 2007 are some of the oldest known in Poland. At Rozpucie, the population of this species has been monitored annually since its first confirmed presence. On the basis of these observations, it can be said that the population has been relatively large and stable each year.

From 2007 to 2012, the number of new localities of S. curvatum grew. The largest numbers of new localities of this insect were described in 2010 and 2012 (Fig. 3).

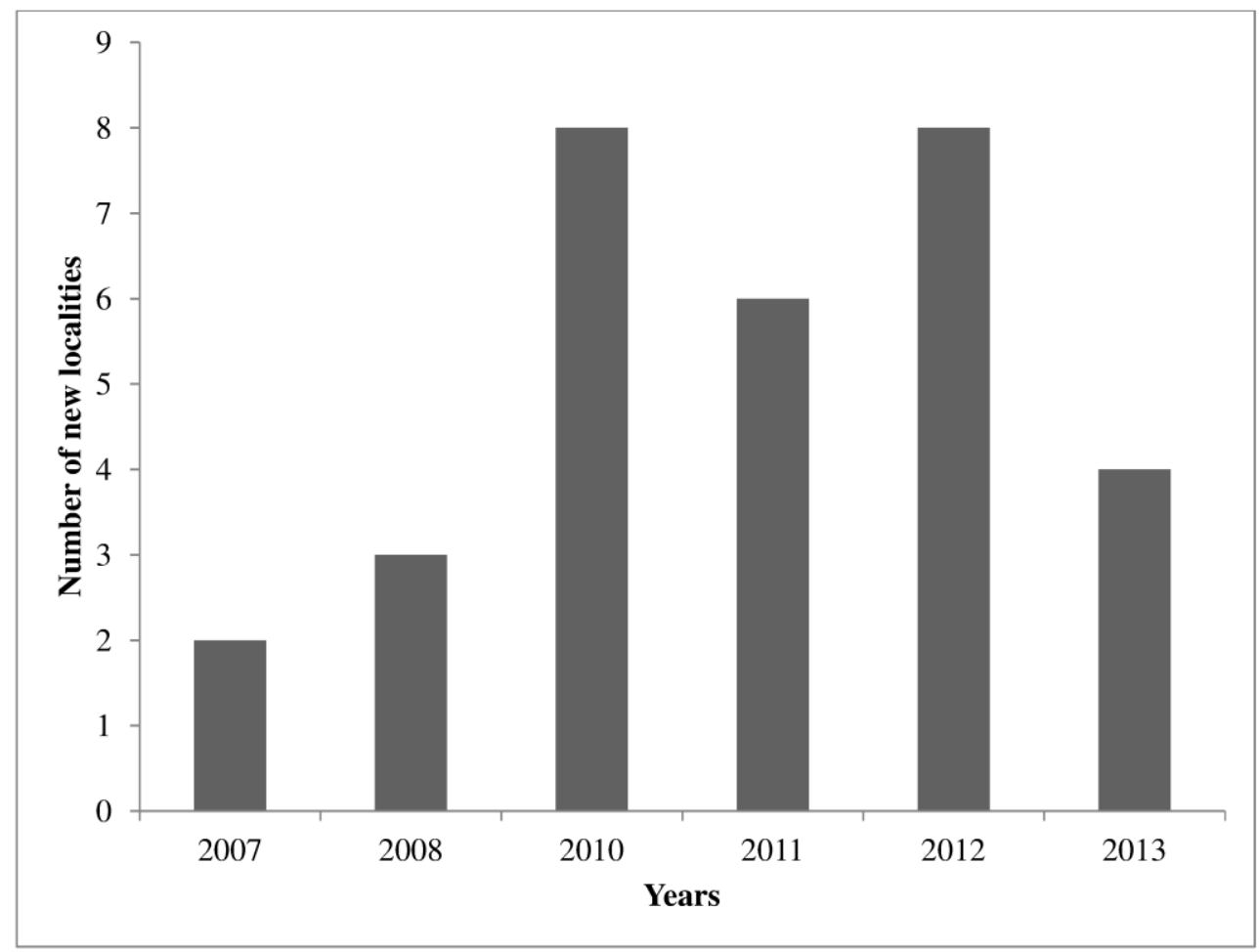

Fig. 3. Number of new localities S. curvatum in Poland described in the years 2007-2013 (without literature data).

The localities of S. curvatum were confirmed in various faunistical regions according to the Catalogue of Fauna of Poland (BURAKOWSKI et al. 2000) (Fig. 2).

Lower Silesia. Wrocław [XS46] - 29 VIII 2011, a nest made up of 5 breeding cells in the frame of a plastic window, leg. et coll. Marcin Kałuża, det. Piotr Bilański. Locality found at a distance of $290 \mathrm{~m}$ from the River Odra canal. 
Kraków-Wieluń Upland. Kraków [DA24] - 13 VII 2010, 1 ex. of a female imago as well as a nest consisting of 4 breeding cells in a flat in the Oświecenie district. The material used to build the nest most likely originated from a construction site located some $500 \mathrm{~m}$ away. The nest, which had been built on an aluminium curtain rail, was destroyed. Photographic evidence of the imago and nest was provided by Anonymous. KrakówDębniki [DA24] - 15 VIII 2010, 1 ex. of a female imago building a nest on a mistletoe decoration and on a shelf behind books. Observation and photographic documentation of the dead specimen in her flat by Anna Perek. Kraków [DA24] - 9 VIII 2010, 1 ex. of a female imago on a window in a room in a building on 29 Listopada Street, leg., det. et coll. Piotr Bilański; 1 VI 2011, 1 ex. of an imago on a window in a room in the same building before a storm, leg. et det. Piotr Bilański. The specimen was destroyed during renovations; 17 VI 2013, 1 ex. of a female imago, in another room of the same building, leg. Zbigniew Kołodziej det. et coll. Piotr Bilański. Kraków-Nowa Huta [DA34] - 14 VI 2011, 1 ex. of a female imago. Observation and photographic documentation of a live specimen in a flat - Anna Król. Kraków [DA24] - 16 V 2012, 1 ex. of a female imago, on the pavement of Wileńska Street, leg. et det. Lukasz Mielczarek, ver. et coll. Piotr Bilański. Kraków [DA24] - 19 VI 2012, 1 ex. of a female imago, in a flat on 29 Listopada Street, leg. Grzegorz Kołodziej det. et coll. Piotr Bilański. Kraków [DA24] - 3 VII 2013, 1 ex. of a female imago, in a kitchen in a building on Żytnia Street, leg. Arkadiusz Fröhlich, det. et coll. Piotr Bilański.

Sandomierz Lowland. Dębica [EA34] - 20 VI 2008, 1 ex. of an imago grown from a breeding cell collected in the attic of a residential building, leg et coll. Andrzej Trzeciak. Rzeszów [EA74] - 23 VI 2010, 1 ex. of a male imago on the pavement next to a footbridge in the city centre, leg. et det. Łukasz Mielczarek, ver. et coll. Piotr Bilański. Łańcut [EA84] - VI-VIII 2010, VII-VIII 2011; a few female imagines building nests in construction pipes in the roof and on storage shelves of a gardening supply store. The insects flew into the store through open windows. Observation by Jarosław Bury. Turza near Sokołów Małopolski [EA76] - summer 2011, a few breeding cells in a ski boot and in a coat in the attic of a house. Observation by Grzegorz Szot. Pawłosiów near Jarosław [FA13] - summer 2012, a few breeding cells in an old jacket in the attic of a house. Observation by Danuta Kopkowicz.

Western Beskid Mountains. Kamionka Mała [DV89] - 2008, 1 ex. of an imago leg., det. et coll. Marcin Widlak. Nest located in a cardboard box in an attic. Bielsko-BiałaStraconka [CA61] - 15 VI 2011, 1 ex. of an imago, in a bathroom. Observation and photographic documentation provided by Przemysław Waluś. Tymowa [DA72] - VII 2010, a nest in an attic. Observation by Małgorzata Fidzińska. Krynica-Zdrój [DV97] - 20 VI 2011, a nest made up of 6 breeding cells in the attic of a house. Observation and photographic documentation provided by Kordian Habel. Jaszczurowa near Mucharz 
Wadowicki [CA91] - 7 VIII 2011, a few nests in the attic of a cottage. Observation and photographic documentation provided by Sylwia Lempart. Przytkowice [DA03] - 18 VI 2013, 1 ex. of an imago on the wall of a house. Observation by Piotr Balcer.

Eastern Beskid Mountains. Rozpucie [FV09] - summer 2007 and 2008, 1 ex. of a female imago in the attic of a house. Observation by Piotr Bilański. 21 VIII 2009, 11-16 VI 2010, 22 VIII 2010 - 1 ex. of a female imago building a nest under a jute bag on a wooden barrel in the attic of a house. On 21 VIII 2009, the nest was made up of around 26 breeding cells. On 22 VIII 2010, it consisted of around 56 breeding cells. 20 VIII 2011, 2 ex. of female imagines; leg., det. et. coll. Piotr Bilański. 1 VI 2012, 1 ex. of a female imago building a nest on a curtain rail in a kitchen. Photographic documentation of the imagines and nests provided by Piotr Bilański. 16 VI 2013, 1 ex. of a female imago on an attic window; leg., det. et coll. Piotr Bilański. Stasiówka [EA34] - 18 VI 2007, 1 ex. of an imago, leg. et coll. Andrzej Trzeciak. Kryg [EV19] - summer 2010, 3 nests made up of 12, 17 and 18 breeding cells; the first was located in the corner of a wardrobe, the other two behind panelling in an attic. Observation, photographic documentation and nest collection by Danuta Druciak. Nests det. et coll. Piotr Bilański. Królik Polski [EV58] - VIII 2011, the presence of a few nests and imagines was confirmed in the attic of a house during roof replacement. Observation by Tomasz Cisowski. Bandrów Narodowy [FV27] - 27 V 2012, a nest made up of 3 breeding cells placed between the rafters and shoring at the top of the roof space of a shed, leg. Tobiasz Sztuba, det. et coll. Piotr Bilański. Mroczkówki near Pielnia [EV78] - 17 XI 2012, a nest located in a house, 3 breeding cells were collected for culturing, leg. Joanna Kobeszko, det. et coll. Piotr Bilański. The culture yielded 1 ex. of a male imago in 2013. Ustrzyki Dolne [FV17] - 19 VI 2012, 1 ex. of a female imago, in a staircase window, Chopin Square, leg., det. et coll. Łukasz Piekarski. Studzian near Przeworsk [FA04] - 5 VI 2012, 1 ex. of an imago drinking nectar on the flowers of a plant of the family Apiaceae LINDL. (Umbelliferae JUSS.). Observation by Marcin Płoskoń. Srogów Górny north-west of Sanok [EV89] - 22 VI 2013 and 15 III 2013, females of S. curvatum at nests in an attic of a wooden house were observed by Paweł Ryba (personal communication to Detlef Mader in 2013). Nests of $S$. curvatum had already been found there in earlier years. Identified on photographs by Detlef Mader. S. destillatorium has also nested in the same attic since at least 2000, and females of $S$. destillatorium have been recorded in the attic and at the nests in various years (identified on photographs by Detlef Mader).

Bieszczady Mountains. Lutowiska [FV25] - VI, VIII August 2010, a few nests in the attic of a house. Observation by Krzysztof Hebda. Rabe near Baligród [EV96] - 27 III 2012 and 31 III 2012, 1 ex. of a male imago in a house. Observation and photographic documentation provided by Marcin Scelina. 
Pieniny Mountains. Kluszkowce [DV47] - 26 VI 2013, 1 ex. of a female imago in a meadow, leg., det. et coll. Marcin Misztela, ver. Piotr Bilański.

\section{DISCUSSION}

Hitherto, there had been 5 known localities of S. curvatum in Poland (BURY et al. 2009, DoBosz 2010, MADER 2013). The large number of new localities is evidence of the dynamic colonisation of Poland by this insect species. The distribution range of $S$. curvatum in Poland presented on the map is temporary and will surely become outdated soon.

According to MADER (2013), the spread of S. destillatorium into new parts of Europe required a few centuries, whereas $S$. curvatum has been able to occupy a similar or even larger area in just a few decades. The migration of $S$. curvatum in comparison to that of $S$. destillatorium is difficult to foresee based on its disorganised, multidirectional and random character not only along river valleys, but also across river valleys and watersheds (MADER 2013).

The first known localities of S. curvatum in Poland were discovered in 2007 in the villages of Stasiówka and Rozpucie. These localities were at distances of 82 and $89 \mathrm{~km}$, respectively, from the city of Bardejov - at that time, the closest known locality in Slovakia reported in the literature (BogusCH et al. 2005). The localities of $S$. curvatum were confirmed in this Slovakian city in 2004. Presumably, this species crossed into and colonised south-eastern Poland via the Tylicz and Dukla Passes. At Rozpucie, S. curvatum most likely appeared as a result of migration from Ukraine. The closest known locality in Ukraine was located in the village of Kolochava (SHORENKO 2003) in 2001, a distance of $160 \mathrm{~km}$ from Rozpucie. According to MADER (2013) the localities of $S$. destillatorium in this part of Poland also resulted from the migration of this species from Ukraine.

Adult specimens of $S$. curvatum can most often be encountered during the growing season, whereas breeding cells can be observed throughout the whole year, and even for a few years after the imagines have abandoned them. Therefore, localities described on the basis of nests should predominate. However, the prevalence of localities described on the basis of sightings of imagines indicates that females choose places to construct their nests that are difficult for people to reach or see. Many S. curvatum nests are hidden in remote parts of attics that are only occasionally and randomly checked, and the small breeding cells of $S$. curvatum may well have been frequently overlooked.

In central European conditions, $S$. curvatum, like $S$. destillatorium, is a synanthropic insect. The synanthropic nature of this species is evidenced by the number of observations of imagines and nests inside buildings, including buildings situated in large cities like Kraków. 
The prevalence of females over males could result from the sex structure of the population as well as their behaviour. Because only females build nests, they are mainly the ones that visit the interiors of buildings, where their presence is easy to confirm. The species is also protandric, like most aculeate Hymenoptera, so by the time nesting takes place, males may be dead or somewhere other than at nests.

Compared to $S$. destillatorium, $S$. curvatum is more difficult to detect. $S$. destillatorium nests on building facades, among other places, where it is quite conspicuous. S. curvatum most often builds its nests in places hidden from view. Its discovery requires the cooperation of the residents of the property, their permission to enter attics etc. Nests of S. curvatum are often discovered by accident and cannot be found by systematic field research and mapping.

The different strategies of these two species regarding nest placement were noted by MADER (2013). According to this author, the nests of S. curvatum, in contrast to the nests of S. destillatorium, are not resistant to rain and the inclement weather conditions that prevail during winter in central Europe may explain their placement in sheltered environments inside buildings.

The majority of observations at the new localities of S. curvatum described in Poland relate to females building breeding cells. In the interiors of buildings, nests consisting of anywhere from a few to a few dozen breeding cells were located near windows or even on the windows themselves. Nests were found, for example, in cardboard boxes and under clothing. The nest with the highest number of breeding cells had been constructed on clothing and under a jute bag. GEPP \& BREGANT (1986) also described a nest located in a work vest.

Only occasionally were observations made outside buildings and their immediate vicinity, e.g. in meadows. This makes it difficult to estimate the population density and distribution in the area studied. Most observations inside buildings were made by persons using the buildings.

S. curvatum tries to conceal its nests. The placement of nests in, for example, the nooks and crannies of clothing where they are invisible at first glance, helps the species to spread by being transported with the clothing, sometimes over significant distances. Even after the discovery and removal of nests, favourable conditions may ensure the survival and development of specimens living in the nests. As a consequence, this leads to the colonisation of new areas. The natural expansion of this species is due to the migration of adult specimens by flight.

Successful colonisation most likely depends on finding the right place to build a nest near a source of mud which is the nest building material. In southern Poland, there is surely no lack of nest building material, while the dense hydrological network also supports the natural expansion of this species. The role of river valleys in the spread of $S$. curvatum in 
Europe has also been noted by SCHMID-EGGER (2005) and MADER (2013).

\section{REFERENCES}

Bitsch J. 2010. Compléments au volume 2 des Hyménoptères Sphecidae d'Europe occidentale (Faune de France 82). Bulletin de la Société entomologique de France 115(1): 99-136.

BITSCH J., BARBIER Y. 2006. Répartition de l'espèce invasive Sceliphron curvatum (F.SMITH) en Europe et plus particulièrement en France (Hymenoptera, Sphecidae). Bulletin de la Société entomologique de France 111(2): 227-237.

BilańSKi P., KoŁodZIEJ Z., PAJĄK M. 2012. Distribution of Sceliphron destillatorium IlLIGER, 1807 (Hymenoptera, Sphecidae) in Poland. Fragmenta Faunistica 55(2): 131-137.

Bogusch P., LIŠKA P., LuKÁŠ J., DUDICH. A. 2005. Spreading and summary of the knowledge of the invasive sphecid wasp Sceliphron curvatum (SMITH 1870) in the Czech Republic and Slovakia (Hymenoptera: Apocrita, Sphecidae). Linzer Biologische Beiträge 37(1): 215-221.

Bogusch P., Straka J., KMent P. (eds.). 2007. Annotated checklist of the Aculeata (Hymenoptera) of the Czech Republic and Slovakia. Acta Entomologica Musei Nationalis Pragae Suppl. 11: 1-300. (in English and Czech).

Burakowski B., Mroczkowski M., Stefańska J. 2000. Beetles Coleoptera. Additions to the volumes 2-21. Katalog Fauny Polski, Warszawa, XXIII(22): 1-252. (in Polish)

BuRy J., SudOŁ D., ZiĘBA P., ŻYŁA W. 2009. New data of occurrence of the genus Sceliphron Klug, 1801 (Hymenoptera, Sphecidae) in Poland. Acta Entomologia Silesiana 17: 11-18. (in Polish)

CAStro L. 2007. Nuevos datos sobre la expansión de Sceliphron curvatum (SMith 1870) en la Península Ibérica (Hymenoptera: Sphecidae). Boletin de la Sociedad Entomológica Aragonesa 40: $537-538$.

Ćetković A, Mokrousov M.V., Plećaš M., Bogusch P., Antić D., Đorović-Jovanović L., KrPoĆETKOviĆ J., KarAman M. 2011. Status of the potentially invasive Asian species Sceliphron deforme in Europe, and an update on the distribution of S. curvatum (Hymenoptera: Sphecidae). Acta entomologica serbica 16(1/2): 91-114.

ĆETKOVIĆ A., RADOVIĆ I., ĐoroviĆ L. 2004. Further evidence of the Asian mud-daubing wasps in Europe (Hymenoptera: Sphecidae). Entomological Science 7(3): 225-229.

Dobosz R. 2010. The first record of Sceliphron curvatum (SMITH, 1870) (Hymenoptera: Sphecidae) in Upper Silesia. Acta Entomologia Silesiana 18: 89. (in Polish)

GePP J., BREgant E., 1986. Zur Biologie der synanthropen, in Europa eingeschleppten Orientalischen Mauerwespe Sceliphron (Prosceliphron) curvatum (SMITH, 1870) (Hymenoptera: Sphecidae). Mitteilungen naturwissenschaftlicher Verein für Steiermark 116: 221-240.

HENSEN, R. V. 1987. Revision of the subgenus Prosceliphron VAN DER VeChT (Hymenoptera, Sphecidae). Tijdschrift Voor Entomologie 129(8): 217-261. 
MADER D. 2013. Biogeography and Migration of the Mud-Dauber Sceliphron destillatorium (Hymenoptera: Sphecidae) in Poland and Surrounding Countries in Europe. Mader Verlag, Walldorf.

Prokofiev A.M., Skomorokhov M.O. 2010. Sceliphron curvatum (F. Smith, 1870), a new in the fauna of Russia and invasive species of digger wasps (Hymenoptera: Sphecidae). Russian Entomological Journal 19(1): 67-70. (in Russian)

Rasplus J.-Y., Villemant C., Paiva M. R., Delvare G., Roques A., 2010. Hymenoptera. Chapter 12. In: Roques A., Kenis M., Lees D., Lopez-VaAmonde C., Rabitsch W., Rasplus J.-Y., Roy D. (eds.). Alien terrestrial arthropods of Europe. BioRisk 4(2): 669-776.

SCHMID-EgGer C. 2005. Sceliphron curvatum (F. SMITH 1870) in Europa mit einem Bestimmungsschlüssel für die europäischen und mediterranen Sceliphron-Arten (Hymenoptera, Sphecidae). Bembix 19: 7-28.

SHORENKo K.I. 2003. New data on the digger wasps fauna (Apoidea: Ampulicidae, Sphecidae, Crabronidae) of Ukraine. Izvestiya Kharkovskogo Entomologicheskogo Obshchestva 10(1): 96-98. (in Russian)

ShorenKo K.I., Konovalov, S.V. 2010. New data on the digger wasps (Hymenoptera: Ampulicidae, Sphecidae, Crabronidae) in the fauna of Ukraine. Ukrainska Entomofaunistyka 1(2): 9-32. (in Russian)

Vecht J. VAN DER, BReugel F. M. A. VAN. 1968. Revision of the nominate subgenus Sceliphron LAtreille (Hymenoptera, Sphecidae) (Studies on the Sceliphronini, Part I). Tijdschrift voor Entomologie 111: 185-255.

VeChT J. van der 1984: Die orientalische Mauerwespe, Sceliphron curvatum (SMITH, 1870) in der Steiermark, Österreich (Hymenoptera, Sphecidae). Entomofauna 6(17): 213-219.

Received: 13 December 2013

Accepted: 2 February 2014 